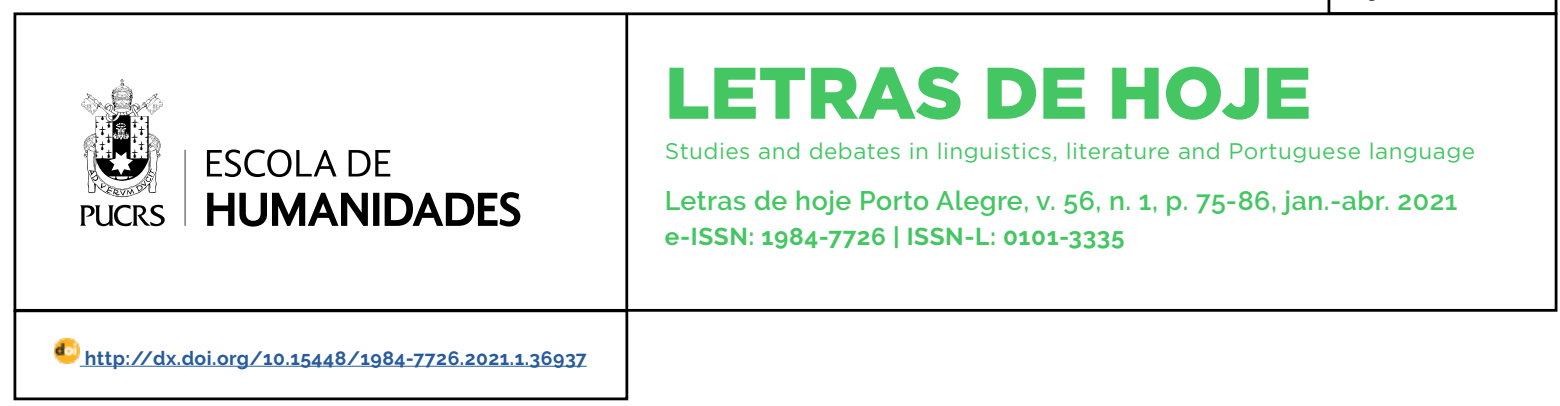

SEÇÃO: TEMÁTICA LIVRE

\title{
Is The Merchant of Venice a Comedy or a Tragicomedy?
}

\author{
o Mercador de Veneza é uma Comédia ou Tragicomédia? \\ ¿El mercader de Venecia es una comedia o una tragicomedia?
}

\section{Carlos Roberto Ludwig ${ }^{1}$ \\ orcid.org/0000-0002-6846-5774} carlosletras@uft.edu.br

Received on: 26 jan. 2020. Approved on: 09 mar. 2021. Published on: 11 jun. 2021.

\section{(c) (1)}

Artigo está licenciado sob forma de uma licença Creative Commons Atribuição 4.0 Internacional.
Abstract: This essay aims at discussing some issues in the play The Merchant of Venice, by William Shakespeare. Even though some may assume that the play is a comedy, the problem of its literary genre is a rather problematic issue today. Some critics debate its inclusion in the comedies because it is not at all a comic play. This discussion is based mainly on Maguire (2004), Gross (2006), Garber (2004) and Auerbach (2007a; 2007b). The label 'comedy' did not suggest that it was a funny play in Shakespeare's age. If some critics think that it is not a comic play, Shakespeare may have designed Shylock as a tragic character. In fact, the play's effects of Shylock's energy and tragic dimensions deeply influenced the audience in the moment when it was first staged. This essay first discusses the problem pathos and inwardness in Shylock's speech. After that, it discusses the issue of the literary genre and argues that it should be classified as a tragicomedy. Keywords: Inwardness; Pathos; The Merchant of Venice; Tragicomedy Genre.

Resumo: Este ensaio tem como objetivo discutir algumas questões da peça o Mercador de Veneza, de William Shakespeare. Embora alguns possam supor que a peça é uma comédia, o problema de seu gênero literário é uma questão bastante problemática hoje. Alguns criticos questionam sua inclusão nas comédias, porque não se trata de uma peça engraçada. Essa discussão tem como base teórica principalmente Maguire (2004), Gross (2006), Garber (2004) and Auerbach (2007a; 2007b). O rótulo 'comédia' não sugeria que fosse uma peça engraçada na época de Shakespeare. Se alguns críticos acham que não é uma peça engraçada, Shakespeare pode ter projetado Shylock como uma personagem trágica. De fato, os efeitos da peça da energia e as dimensões trágicas de Shylock influenciaram profundamente o público no momento em que foi encenado. Este ensaio discute primeiro o problema de pathos e interioridade na fala de Shylock. Em seguida, discute a questão do gênero literário e argumenta que deve ser classificada como uma tragicomédia.

Palavras-chave: Interioridade; Pathos; O Mercador de Veneza; Gênero Tragicomédia.

Resumen: Este ensayo tiene como objetivo discutir algunos temas de la obra El mercader de Venecia, de William Shakespeare. Aunque algunos pueden asumir que la obra es una comedia, el problema de su género literario es un tema bastante problemático en la actualidad. Algunos críticos debaten su inclusión en las comedias, porque no se trata en absoluto de una obra cómica. Esta discusión se basa principalmente en Maguire (2004), Gross (2006), Garber (2004) y Auerbach (2007a; 2007b). La etiqueta "comedia" no sugería que fuera una obra divertida en la época de Shakespeare. Si algunos críticos piensan que no es una obra cómica, Shakespeare puede haber diseñado a Shylock como un personaje trágico. De hecho, los efectos de la energía de Shylock y las dimensiones trágicas de la obra influyeron profundamente en la audiencia en el momento en que se representó por primera vez. Este ensayo primero analiza el patetismo y la interioridad del problema en el discurso de Shylock. Posteriormente, discute el tema del género literario y argumenta que debe catalogarse como una tragicomedia.

Palabras clave: Interioridad; Pathos; El mercader de Venecia; Género de tragicomedia. 


\section{Introduction}

Someone may ask whether The Merchant of Venice is not just a comedy. The use of such genre may be suggestive because it enables to introduce ambiguities in the text, letting the reader and the audience feels ambivalent reactions: on the one hand laughing at Shylock's comic traits and at the play's happy ending, on the other hand, bitterly feeling the awkward sensations that Shylock is simply ruined without moral scruples. The tragic and comic opposition in the play constructs the character of the play, especially Shylock, as a rather complex character. His anger and his rage may seem comic, but they suggest and represent his inward feelings and dimensions: his hatred, desire of revenge, resentment and anxieties.

Though some assume that The Merchant of Venice is a comedy, the problem of the literary genre of play is problematic issue today. Some critics have pointed out that the play was tragically designed. It is not a comic play, but an uncomic comedy. They criticize the inclusion of The Merchant of Venice in the comedies because it is not at all a funny play. The label 'comedy' did not suggest that it was a funny play in the age. If some critics think that it is not a funny play, Shakespeare may have designed Shylock as a tragic character. In fact, the play's effects of Shylock's energy and tragic dimensions deeply influenced the audience in the moment when it was first staged. The play was published in the Stationers' Register with an alternative name: The Marchaunt of Venyce or otherwise called the Jewe of Venyce. It seems that the audience's aesthetic reaction instigated Shakespeare to add a second name which drew attention to Shylock. In fact, Shylock embodies both tragic and comic features. He does not deny the consequences of bond, because he tragically accepts its consequences and his desire for revenge.

In some moments, this discussion seems to be 'defending' Shylock. Nonetheless, it is a crying need for choosing a point of view when reading and analyzing such a polemic play as The Merchant of Venice. Moreover, it is not only an issue of this research, but surprisingly it is also a tendency noticed in our contemporary criticism, especially from the 1980s, that sees Shylock simultaneously as a villain and a victim. If there is a reactive remainder in literary criticism against the $20^{\text {th }}$ century anti-Semitism and the horrors of Auschwitz, it is not surprising at all that the contemporary readings of the play seem to 'defend' Shylock. ${ }^{3}$ In that sense, for example, Derek Cohen (2003) reveals that

\begin{abstract}
it is not merely inevitable that these two characters [Shylock and Caliban] themselves are historical subjects, but also that today it is difficult, and even morally problematic, read Shakespeare's Jew and his Slave as though the concentration camps and the institution of slavery never happened; to read them purely historically, that is, and to concomitantly obscure the terrible consequences of a marginalization that in Shakespeare is relatively benign. I attempt thus to link Caliban and Shylock to the subsequent histories of their nations or kinds by an examination of the contemporary contexts of marginalization described by the plays and to link that context to a larger and more catastrophic history, a history as old as social experience. (p.13)
\end{abstract}

Thus, the focus of the analysis may fall on Shylock's inwardness and pathos, pointing out his suffering and resentment towards the Christians represented in the play. Consequently, if one regards Shylock as the hero of the play, rather than Antonio, the discussion may reconsider the literary genre of the play. This discussion is based mainly on Maguire (2004), Gross (2006), Garber (2004) and Auerbach (2007a; 2007b)

\section{Pathos and Inwardness}

The Merchant of Venice is a play specially focused on appearances and subtle inner feelings of the characters. It is a play that represents the paradoxes between outwardness and inwardness, which is suggested by the Shakespearean mirroring

\footnotetext{
3 See, for example, Martin Coyle's new casebook on the play, called The Merchant of Venice: contemporary critical essays, (1998) Kaplan's essays in his The Merchant of Venice: Texts and Contexts, (2002); Kenneth Gross' book on Shylock, called Shylock is Shakespeare, 2006; Janet Adelman's book Blood Relations, 2008; Charlton's Shakespearean Comedy, 1984; Derek Cohen's Searching Shakespeare: Studies in Culture and Authority, 2003; Jordan's and Cunninghum's The Law in Shakespeare, 2010; Laurie Maguire's Studying Shakespeare. 2004; and James Shapiro's Shakespeare and the Jews, 1996.
} 
device, silences, non-said, bodily gestures, breaks of language and twists of language. But inwardness was a Renaissance issue emerging from previous forms of the representation of an inner self in other literary forms. However, outwardness was supposed to be false, deceitful, and even dangerous, whereas the notion of the inwardness was seen as true and sincere, even though it was imperceptible to the senses. The forms, molds and shapes of the appearances could be calculated pretentions, which may not be seen as the symptoms of a truthful inward disposition of the mind. Such paradox was not at all an unfamiliar issue to Shakespeare's coevals. Thus, to overcome this gap certain forms of discourses described and identified discursive traits, which constituted the constellations of the rhetoric of inwardness in that age (MAUS, 1995).

Inwardness is an inward space of the self, which is constituted by feelings, thoughts, and ideas which appear in ever so subtle and sometimes puzzling details of the text. In fact, inwardness is the resulting perceptiveness of an inner space of the individual. The notion of this inward space and inwardness is perceived, on the first and most obvious level, in acts and attitudes; secondly, in poetical constellations which permit to make inferences about the characters' conscience and their ethical decisions; in moments of indecisions and crises; or, more subtly and often overlooked, in the enigmas of bodily gestures, conscience, verbal slips, silences, implicit meaning in words and language, and pathos. They are determined by some mysterious forces ${ }^{4}$ of the self's unconscious, which cannot be controlled and pop up in bodily feelings and paradoxical ideas. There is a connected relation between conscience and judgement, i. e., when someone judges a person, there pops up dimensions of inwardness and subjectivity which interferes in judging someone. (FERREIRA; LUDWIG, 2019). Inwardness is, therefore, the inward dispositions of the self wherein thoughts, feelings, ideas, and anxieties are floating and are incrusted in the individual's unconscious.
Considering inwardness as an epochal cultural construct, its traits and shapes are quite different from the modern concept of subjectivity. Inwardness is still a broader concept in English Renaissance Age, rather than our modern concept of subjectivity, which is inevitably pervaded by philosophical concepts and psychoanalytic assumptions, as discussed by Ludwig (2018; 2020, in press).

In his work Mimesis, Erich Auerbach points out Shylock's complexity and human dimensions. For Auerbach, though Barabbas in The Jew of Malta, by Marlowe (2003), possesses more greatness than Shylock:

\begin{abstract}
Shakespeare acknowledged and understood with more depth the human problematicity of his Jew. For him, Shylock is, regarding his social position and considering the aesthetic view, a lower figure, unworthy of the tragic. whose tragicity is invoked during one moment, but it is not more than a flavor of a triumph of a higher humanity, nobler and freer, and also more aristocratic. (2007a, p. 280).
\end{abstract}

Likewise, Richard III is a rather villainous and vicious character, even though he expresses remorse and conscience at the end of the play, as discussed by Ludwig (2017). On the other hand, Shylock's inward dimensions and human feelings are not determined simply by his actions. According to Auerbach, there is a notion of destiny, not in the ancient sense, but in the sense of life experience which precedes the action itself. Auerbach focuses his analysis on the idea of destiny, not in the Greek sense, but as the configuration of the character's pre-history and on-stage actions.

Due to a multiplicity of themes and to the remarkable liberty of movements of the Elizabethan theatre, there are clearly shown, in each case, a special atmosphere, life conditions, a pre-history of the characters; [...] we can observe thus many other things on the main characters; one makes a big picture of his normal life and of his peculiar character. independently of the plot wherein he is involved now. Thus, destiny means here something more than the current conflict. In ancient tragedy, it is almost possible to distinguish clearly between the natural character of the personage and the destiny he is doomed to. In Elizabethan tragedy, we are faced in many cases, not only to the purely natural character, but to a cha- 
racter already pre-determined by birth, vital circumstances, by his own pre-history (that means, by destiny); a character in which destiny already partakes in a great measure, before it is accomplished in the form of the tragic classic determined conflict; this is often only the motif through which a tragicity long ago in process is realised. This is seen with special clarity in Shylock's and Lear's cases. What happens to each one is especially destined to them, for the special character of Shylock and Lear, and such character is not only natural, but pre-formed by birth, situation, pre-history, that is to say, by destiny, when it reaches an unmistakable peculiarity and the tragedy destiny to him. (AUERBACH, 2007a, p. 284-285)

Pre-historical seems to refer here to a set of life experiences which one can imaginative build from the character's behavior, feelings, thoughts, ideas and gestures. His condition as an outcast, his problematic relation to both Antonio and Jessica makes his own deeds to go against him. $\mathrm{He}$ is a sort of victim of his own actions and of his circumstantial situation as a usurer and a Jew. Such situation is enhanced by his being despised by the Christians in the play, overcharging his anger and bitterness against him. In a similarway, Antonio's destiny or pre-history determines his actions and attitudes. For example, his sacrificing attitude for Bassanio's sake, as well as his sadness and discontent determine his relationship to the other. The pre-history of the characters and of the play suggests and represents the characters attitudes, actions and inwardness.

In that sense, pathos is depicted in Shakespeare's plays and may considered a device of representing inwardness. ${ }^{5}$ According to Staiger, pathos normally breaks the grammatical rules and 'goes directly from a high point to another one in the speech' (1997: 120). Therefore, when Shylock expresses his inward feelings through pathos, it violates grammatical normativity to represent the inward disruption and laceration in his feelings, thoughts, and mysterious dimensions. Such twisted uses of language enhance strength, depth and laceration in Shylock's pathos. Shakespeare mingles different syntactic forms in order to modulate the rhythm of Shylock's speech, which creates ambiguous dimensions whose meaning is pervaded by tension and ambiguity. His feelings make him confused, so that language is disrupted intensifying such confusion. Shakespeare introduced the mimesis of inwardness by breaks and twists of language, pathos and modulated rhythm in Shylock's speeches, as in his famous speech / am a Jew.

In Shylock's most famous speech we can see his complex humanized dimensions. Salerio asks Shylock what is the use of a pound of flesh: 'Why, I am sure, if he forfeit, thou wilt not take his flesh: what's that good for?' (SHAKESPEARE, 2010: 283) Then Shylock answers such question in his most astonishing and touching speech:

\begin{abstract}
To bait fish withal: if it will feed nothing else, it will feed my revenge. He hath disgraced me, and hindered me half a million; laughed at my losses, mocked at my gains, scorned my nation, thwarted my bargains, cooled my friends, heated mine enemies; and what's his reason? I am a Jew. Hath not a Jew eyes? hath not a Jew hands, organs, dimensions, senses, affections, passions? fed with the same food, hurt with the same weapons, subject to the same diseases, healed by the same means, warmed and cooled by the same winter and summer, as a Christian is? If you prick us, do we not bleed? if you tickle us, do we not laugh? if you poison us, do we not die? and if you wrong us, shall we not revenge? If we are like you in the rest, we will resemble you in that. If a Jew wrong a Christian, what is his humility? Revenge. If a Christian wrong a Jew, what should his sufferance be by Christian example? Why, revenge. The villainy you teach me, I will execute, and it shall go hard but I will better the instruction. (SHAKESPEARE, 2010, p. 284 - 285).
\end{abstract}

First of all, he presents his reasons for his bond. The desire of revenge and his reasons for it are clearer now, though he had already mentioned them beforehand in the play. All his losses were caused by the Christians, as well as by his daughter, who is now a converso. He unveils that Antonio was bound to disdain his way of earning money and his customs, such as religion, faith, and nation. The only reason for Antonio's ill-treatment to him is because Shylock is a Jew. Thus, he claims that a Jew has the same feelings, affections, desires, organs and dimensions as any Christian has. Jews are subject to the same vicissitudes of life as a Christian is, such as poisoning, hurting, 
and dying. However, he uses such comparisons to justify that if a Christian can take revenge, so the Jews will take the same revenge. Although the Christians highly praise the value of 'mercy', they are as merciless to Shylock as he is to them.

Finally, Shylock reveals that Antonio and the Christians' deeds have taught him to be merciless, revengeful, perfidious, and villain: 'The villainy you teach me, I will execute, and it shall go hard but I will better the instruction.' (SHAKESPEARE, 2010: 285). ${ }^{6}$ The Christians think that he cannot claim for justice and no one can revenge their deeds. Shylock is his own avenger and of his nation; he is the incarnation of the avatar 'of the terrifying patriarch with the knife' as Adelman states (2008: 131). The point is that Shylock's villainy and mercilessness are due to Antonio's mistreatment and violence. He mirrors what all the Christians have done against him. He justifies his right for justice with the lex talionis which states that the law must follow 'an eye for an eye, a hand for a hand'. However, the Christians are hypocritical when they say that Shylock is villain and they are merciful and generous. They do not acknowledge that Shylock can, by his own means, claim for the lex talionis.

His energy in this speech is quite enigmatic. He makes the audience feel the pity for his loss, his anger, anxiety, desire for revenge, and his resoluteness for it. His pathos is vibrating and deep, because he is simultaneously mourning the loss of his daughter 7 , money and roaring his inward rage against Antonio. His inwardness is represented in its deepest dimensions and we see that his humanity is enhanced by this energy, strength and vigor of such inward feelings coming out so violently. As Cohen points out (1980: 59): 'He is a suffering human being.' In fact, many critics analyze his speech as a claim for his humanity, such as Goddard (1963), Charlton (1984), Hinely (1980), Sherman (2004), Cooper (1970), Cohen (1980). His humanity is enhanced by his suffering.

Furthermore, in this speech there are some syntactical details which enhance his pathos and the effects of Shylock's speech. At the beginning of the speech, he uses the present perfect (hath + past participle), a tense which suggests that an action which happened in the past still has its effects in the present. Thus, one could imagine he still feels their effects inside him: Antonio's mistreatments make Shylock feel resentment, bitterness, and anger: 'He hath disgraced me, and hindered me half a million; laughed at my losses, mocked at my gains, scorned my nation, thwarted my bargains, cooled my friends, heated mine enemies; and what's his reason? I am a Jew.' (SHAKESPEARE, 2010: 284). Shylock complains revealing Antonio's disrespect for him. He starts the speech using the formula 'he + hath + past particle'. He parallels many action verbs in the past particle in order to enhance Antonio's mistreatment to him. The use of this syntactic parallelism enhances the acts done by Antonio against Shylock. They are altogether eight different actions which aimed at affronting Shylock: disgraced, hindered, laughed, mocked, scorned, thwarted, cooled, and heated. All of them have negative meaning in his speech. Such despising attitudes signal that the Jews are not respected by the Christians in the play.

When he stops the speech at the sentence 'I am a Jew', which achieves one of its heights of tension and passion, he inverts the grammatical structure of his prose. Now Shylock asks rhetoric questions, which refers to obvious truths about humanity: 'Hath not a Jew eyes? hath not a Jew hands, organs, dimensions, senses, affections, passions?' Here he changes from the present perfect to the use of the simple present. Simple present is normally used to express habitual actions or universal truths. It is evident here that Shylock is using just rhetorical questions to enhance his human condition and to remember the Christians and the audience that he is human being as any Christian on stage. Shylock's employment of parallelism dovetails with J. M. Coetzee's analysis

\footnotetext{
6 In the same way, Shakespeare puts a similar speech in Macbeth's mouth, as he fears his conscience: 'But in these cases / We still have judgment here; that we but teach / Bloody instructions, which, being taught, return/ To plague the inventor: this even-handed justice / Commends the ingredients of our poisoned chalice / To our own lips.' (Macbeth, I, vii, 7-12)

7 In love poetry pathos is common place which enhances the lover suffering and pain. For an example, see Aguiar and Ferreira (2018).
} 
about parallelism in his essay The Rhetoric of the Passive in English. For Coetzee,

Parallelism, periodicity, and balance and/or antithesis are structures that in fact lend themselves rather readily to interpretation. Balance and antithesis are above all principles of ordering: parallelism (a more fundamental operation, and more widespread in language) creates what we can call temporary semantic equivalents between parallel elements, and periodicity is a syntactic image of closure (no addition to the structure is possible). (1992, p. 163).

Thus, such parallelisms and repetitions in Shylock's speech enhance the rhythm and pathos of the speech. Shylock balances his feelings, both positive and negative, which unveil the ambiguities of his character. The rhythm of his speech is quite intense and quick, jumping from word to word. Such intense, energetic and quick rhythm is also intensified by alliterations, mainly the fricative ones, such as $/$ th $/, / \mathrm{s} /$ and $/ \mathrm{f} /$, and the nasal ones, such as /an/, /en/ and/ions/. as well as the plosive ones such as $/ \mathrm{p} /, / \mathrm{t} /, / \mathrm{k} /$. In that sense, Emil Staiger (1997) analyzes the main aspects of the drama. He highlights that the goal of such intense and 'complex' rhythm in pathos 'is not to contaminate us with the 'mood', but to purify the atmosphere with rude strikes as those of a tempest'. (1997, p. 123). Such mood is produced and represented by alliterations, which reveal and intensify his disturbed and confused suffering and inward feelings.

After that, he twists the structure of the sentences to reassert a rather general view of his human condition: 'fed with the same food, hurt with the same weapons, subject to the same diseases, healed by the same means, warmed and cooled by the same winter and summer, as a Christian is?' (SHAKESPEARE, 2010, p. 284). Once again, it is a sentence filled up with alliterations enhancing his inward floatation and feelings. Moreover, he uses past participle in the passive voice as a rhetoric device. Its main effect is to efface the agent of the action. It demonstrates more general and universal ideas of the human condition, as well as his similarity to the Christians. He breaks the grammatical rule, not introducing the passive verb with the verb 'to be', but he simply repeats the structure with parallelism. The grammatical devices depict his inward confused state, signaling his inner rupture and suffering.

In that sense, J. M. Coetzee (1992) makes a ground-breaking analysis of the use of the passive in literature. He states that it is a device used by many classical authors to twist the meaning of the sentence and reverse the proposition of the sentence against those who criticize or practice the actions in the propositions. He focuses his analysis on passivisation, a rhetoric operation which deals with and intends hidden meaning in the text. Rhetoricians argue that the use of the passive can affect 'the focus of a sentence, the active form can consolidate the superficial subject as "hero" where the passive would consolidate the subject as "sufferer"' (1992, p. 150). Thus, the focus on passive sentences answers rather to a 'preference for objectivity and distance, which seeks for avoiding personal attachment, commitment, and responsibility to one's speech'. (1992, p. 150). In classical terms, passivisation was named hyperbaton. Rhetoricians always tried to analyze the infringement of the natural order of the sentence, whose order is disturbed and whose meaning are changed (COETZEE, 1992, p. 150). Thus, Coetzee presents some important aspects of classical passivisation or hyperbaton:

\begin{abstract}
In the interest of aesthetic appeal, or for the sake of emphasis, or (in Longinus) for the sake of representing dramatically states of inner passion, transgressions of the natural, logical order may take place. [...] Hyperbaton must be used sparingly, since it depends for its effectiveness on the maintenance of the norm of natural word order. (1992: 151).
\end{abstract}

Coetzee argues that in classical English writers, such as Defoe, Swift, Gibbon and Henry James there is a rather intense use of the passive and of the agentless sentence as a rhetorical device. Such device tends to abstractness, generality, and irony, i. e. 'the aristocratic mode of irony' (1992, p. 159). Such authors also employ twists in language which reverse the expected idea proposed by the passive. In Coetzee's opinion, the analysis of the implicit meaning of the passive, specifically the short passive, that which 'the agent 
is "never there"' can be sustained by 'comparative, historical, and psychological' evidence (1992, p. 173). For him, a way of thinking the passive is to consider them as

sentences whose agent is not merely veiled (but still there behind the veil) or deleted (but once present) or unexpressed (but thought), but is actually null, void. The short passive is the principal means language provides to enable us to talk about acts as though they occurred without agents. (COETZEE, 1992, p. 173).

Thus, meaning and form are twisted together in order to create multiple and ambivalent meanings, which are enhanced in the twist of the form. (COETZEE, 1992, p. 174). In that sense, Shakespeare also uses the passive ironically, because in this speech Shylock does not mention anything directly about the Christians; however, one can infer that the Christians are being targeted when he utters verbs in the passive. By omitting the agent in some of the sentences of Shylock's speech, Shakespeare creates a vague but known and foretold idea of what is behind the characters' faces in the play: the Christians are represented as a mirror of Shylock and they are hypocritical by criticizing him, yet they try to hide that they injured Shylock. He is trying to enhance his condition as a sufferer and a victim, revealing that the causes of his anger and anxiety are Christian actions and mistreatment. In that sense, Coetzee enhances that the passive,

despite its convenience, leaves an uneasy feeling: it opens up an area of vagueness that can simply be skated over (as most of us do in everyday usage), but that can be explored and exploited for their own ends by writers who take seriously the question of whether language is a good map of reality. (1992, p. 174).

Such 'uneasy feeling' is enhanced throughout the play, but it gets at its top in this speech. Even though Shylock uses prose when he speaks, its tension is emphasized by the use of passive. To a certain extent one can say that 'God' may be the agent of some actions, being thus more of a Job's God who gives and takes away a man's blessings. Nonetheless, 'hurt with the same weapons' are, in fact, Christians' deeds in the play. By paralleling human actions with the inexorable fate any human being must endure, Shylock confesses his fate and points to the Christians attitudes in the play. He is also ironic stating that he was 'hurt with the same weapons', which suggests that as he is hurt by Antonio, he can take the same weapon against the merchant.

After that, Shylock swerves the syntactic construction of his speech: he introduces the conditional as a way of enhancing his humanity through hypotheses which work as merely rhetorical questions:

If you prick us, do we not bleed? if you tickle us, do we not laugh? if you poison us, do we not die? and if you wrong us, shall we not revenge? If we are like you in the rest, we will resemble you in that. If a Jew wrong a Christian, what is his humility? Revenge. If a Christian wrong a Jew, what should his sufferance be by Christian example? Why, revenge. The villainy you teach me, I will execute, and it shall go hard but I will better the instruction. (SHAKESPEARE 2010, p. 285).

More precisely, he uses here the Zero Conditional with the lexical mark 'if'. It 'expresses 'certainty rather than possibility', according to Oxford (2010: R33). ${ }^{8}$ Such usage implies a rather informal, loose and familiar language, which syntactically is not so well-structured as the First, Second or Third Conditional. 9 This form of the verb conveys something that is universally accepted as true. Thus, it reveals his pathos and inward confusion, hatred, and resentment. After that, in the final part of the speech he seems to become more rational; his feelings are not so confused, because he thinks more rationally and organizes his speech structurally. Such rational tone is enhanced syntactically by the elaborated use of the 'First Conditional with if' and the willfuture (OXFORD, 2010: R33). ${ }^{10}$ Now he is coming back to what he was initially in the play: thinking,

8 The Zero Conditional requires the employment of verbs only in the present or in the past tense. (OXFORD, 2010).

9 The first conditional is constructed with an if clause in the present tense and the main clause in the future tense, as in If I have money I will buy the book; the second conditional is built with and if clause in the past tense and the main clause in the conditional tense, as in If I had money, I would buy the book; and the Third conditional is built with an if clause in the past perfect and the main clause in the conditional perfect tense, as in If I had had money, I would have bought the book. For more details, see Oxford (2010: R. 33.)

10 The first conditional is built with a verb in the present and another in the will-future (OXFORD, 2010: R33). 
pondering and counterbalancing the pros and cons of his revenge. Thus, Shylock cries out his resentment, anger and his deep suffering through some breaks in the grammatical norm.

Therefore, in Shylock's speech pathos his inwardness comes out. It is enhanced in such speech by his anger, desire of revenge, resentment, and skeptical thought. According to Staiger (1997), in his analysis of the drama, originally pathos meant 'living, experience, misfortune, suffering, passion, and many other expressions' (1997, p. 121). Shylock's experience and endurance of the Christian mistreatments against him and his people are enhanced and revealed by his pathos in this scene. 'Man is moved by passions', Staiger states (1997, p. 121). Shylock's energy and perturbation signals his inward feelings. Thus, the speech of the dramatic character is quite appropriated to his feelings, which act on his passions overwhelming him. (STAIGER 1997, p. 121). His pathos may be felt as exaggerated and even histrionic. Nevertheless, Staiger points out that whereas in the lyrical poetry feelings are quite inwardly kept, in the action of the pathos feelings are not much discreet. As Staiger defines, the action of the pathos implies

resistance - a rude clash or mere apathy - which tries to shatter with impetus. Thus, stylistic peculiarities are explained in this new situation. The pathos is not spread out in our inner self; it must be engraved many times by force in our inner self. The context of the sentence does not dissolve itself oneirically as in the lyric work, but the whole strength of the speech is cored on loose words. (1997, p. 122)

For Staiger, such twists are intentionally made by the dramatist, who proves that he violates the verse and its language spontaneously (STAIGER 1997, p. 124). With such intentional twists and breaks Shylock tries to persuade the Christians and the audience of his human condition. What moves him is his desire and will to recover his daughter, money, honor, and respect. In this sense, 'the pathetic man is moved by what must be and his passions invest against the status quo.' (1997, p. 125). Shylock does not accept his loss of respect, lineage, and gains; he fights against his entourage instead.
Furthermore, there is something noble in Shylock's pathos. According to Staiger such noble dimension in pathos is because the status quo is always beyond of that what moves pathos (1997, p. 126). Shylock's pathos is moved by his honor and respect. Pathos is elevated, noble, and deep. Hence, it is a way the dramatist can elevate the characters, because even though they are lower people, they are able to express their feelings and inwardness through pathos. The grandeur or nobility of pathos dwells on the factuality of 'being ahead' of his status quo. (STAIGER 1997, p. 126). In many senses, Shylock is ahead of his entourage, because he perceives that the Christians are hypocritical and cynical and do not consider him as a human being, always treating him as a stray dog. In a subtler level, he represents a rhetorical device to point the Christians' contradictions, who are no longer able to smooth over them.

Furthermore, Staiger sums up the intentions of the use of pathos in dramatic works and its effects:

Everything leads to this: the impetuous rhythm is due to the tension between present and future, the strikes which affect us as an unquestionable exigency, and the pauses show the vacuity of the inexistent as the vacuity in which the status quo is absorbed, the situation to be changed. (STAIGER 1997, p. 126)

What Shylock foresees is the vacuity of his loss. He tries to revenge himself and cry out against the Christians as a retaliatory act, as a reaction to satisfy his anger and resentment. However, as soon as he claims for justice in the trial scene, he will be obliged to face his fate and accept his ruin imposed by Portia and the Christians. Thus, the bend of such devices aims at representing floatation of Shylock's inwardness.

Shylock feels and expresses pathos, whose meaning and feelings have received deep Christian dimensions. In that sense, Erich Auerbach (2010b) analyzes the historical development of the meaning pathos/passio in Western tradition, in his essay Gloria passionis (2007b). Originally, for Aristotle pathos meant a spasm. It maintained the meaning of 'suffering' and 'passivity', 'as well as its ethical neutrality. No one could be praised or reproved because of his pathos' (2007b, p. 77). 
Later on, with the stoical moral, pathos (passio in Latin) assumed negative connotations of 'inquietude' and 'compulsive movement which destroy the wise man's peace' (2007b: 77). For the stoics it was something to be avoided, 'it was a wise man's duty to be impassibilis, to keep him, at least inwardly, imperturbable by the world' (2007b, p. 77). Then there came images of tempest and the agitation of passions to represent pathos, as well as sometimes pathos was substituted by perturbation. In this second moment of the semantic development of pathos/passio the word was associated to violence and activity, due to the stoical interference in the meaning of passio/pathos (2007b, p. 77).

However, Saint Augustine deeply changed the meaning of pathos/passion in his work De Civitate Dei. The stoical idea of pathos/passio as something to be avoided, negative and disgusting was substituted by the idea of pathos as something good - bonae passiones (2007b, p. 79) For Auerbach, 'the Christian authors did not oppose passions to the tranquility of the wise man, but the submission to injustice - its intention was not that one of escaping from the world in order to avoid the suffering and passions, but to transcend it through suffering.' (2007, p. 79). Moreover, it was Ambrose of Milan who enlarged the idea of good sentiments of passio/pathos to something sublime, meaning that pathos/passio was something glorious: the gloria passionis, the glorious passion. Then, the Church Fathers' Christian forlorn associated pathos/passio to Christ's passion and, later on, it was associated with ideas of love, both sensual and charitable one. Such erotic reading came from the reading of the Song of Songs by Bernardo, who associated pathos/passio to love, both sensual and divine love. Thus, passion became something sweet and bitter, 'bitter and salutary' (2007b, p. 85), and it also meant 'sufferance' and the 'ecstatic creative amorous passion' (2007b, p. 86). As a result, pathos was associated with other love motives in later poetry and drama, such as 'ardor', 'love', 'fervor', and 'inebriety' (2007b, p. 89). Therefore, in comparison to all previous ideas of pathos/ passio, it turned out to be something praised and sought for in the late Middle Ages and in early Renaissance. Despite that, its ambiguity is embodied in its modern concept: pathos/ passio is seen as something good and terrible simultaneously. In the end, Auerbach makes clear that pathos/passio 'always comes from superhuman powers - from the depths as well as from the heights - it is always received and endured as a magnificent and terrible gift.' (2007b, p. 93).

Therefore, Shylock's pathos is expressed not to avoid the world or to avoid his fate, but to face injustice. He is not submissive, since he wants revenge and justice; thereby, he lets his own passions overwhelm him and his action. He wants to recover his daughter and his money, as well as he wants to revenge himself from Antonio. That is why his sufferance and feelings make him act. One feels quite disquieted when one sees Shylock's rage, anger, and desire for revenge. That is the dramatic device that Shakespeare created and employed in the play to represent Shylock's inwardness and to make him a rather complex and deeper character. Shakespeare built, with impressive ability, the mimesis of inwardness in Shylock's character, representing his inwardness by repetitions, floating, confused, and disrupted feelings and pathos.

\section{Is the play a comedy or a tragicomedy?}

Though some assume that The Merchant of Venice is a comedy, the problem of the literary genre of play is not a well-solved issue until today. Some critics have already pointed out that the play was tragically designed, as Nicholas Rowe, Heine and Ulrici affirmed. In a similar way, Laurie Maguire has recently pointed out that the play is 'a deeply uncomic comedy' (2004, p. 147), because 'the last scene is unusually private and anti-social. It is also indifferent to the preceding events: the characters indulge in bawdy jokes, oblivious to the fact that they have just destroyed a man.' (2004. p. 149). Also, Graham Midgley, in The Merchant of Venice: a reconsideration (1969), recognizes the difficulty in reading Shylock and the tendency to forget the events of the trial scene (1969, p. 191). Thus, he criticizes the inclusion of The Merchant 
of Venice in the comedies because it is not at all a funny play (1969, p.195).

The label 'comedy' did not imply that it was a funny play in Shakespeare's Age. They were represented in the Festivals. Comedy can be defined as a play that represent funny situations through artistic devices, which make the reader or the audience experience comic. (MAGUIRE, 2004; GARBER, 2004). Tragedy, on the other hand, represents the tragic fate of a hero who may pay his faults (hybris) with death (MAGUIRE, 2004; GARBER, 2004, ARISTOTLE, 1980).

Other Shakespeare's plays present similar traits to Shylock's play. For example, in Much Ado about Nothing there emerges a dramatic plot, when Hero is unfairly accused of having lost her virginity. Despite that, the play ends in a happy-ending scene with the couple's reconciliation and marriage. Furthermore, according to Marjorie Garber (2004),

The term 'festive' refers not so much to the plays' presumptive joyousness as to their thematic links and plot links to seasonal festivals from May Day to Christmas and Twelfth Night, and it is noteworthy that in each of these plays, especially the Merchant, there is much that actively resists joyful celebration. (2004, p. 284-285).

Thus, The Merchant of Venice cannot be simply classified among the comedies because it seems more a tragicomedy. For Janette Dillon (2010), The Merchant of Venice just as Much Ado about Nothing could be included among the tragicomedies. In her opinion, 'tragedy seems narrowly avoided' in those plays. 'Indeed, in that both these plays 'want deaths' but 'bring some near it', they arguably fit Fletcher's definition of tragicomedy better than the latter group' of Shakespeare's plays (2010, p. 171), such as Pericles, Cymbeline, The Tempest and The Winter's Tale. She builds her argument based on John Fletcher's The Faithful Shepherd, which pointed out that the tragicomedy's plot was between tragedy and comedy, and that it does not represent death, but it 'brings some near it', which does not mean that it is simply a comedy (2010, p. 170). For Dillon, there is no consensus among the critics about 'what generic name to give to the group of Shakespeare's late plays' (2010, p. 170). Some approaches concentrate on their tragicomic aspects, whereas others concentrate on their comic aspects and happy endings. Thus, I argue that The Merchant of Venice is a tragicomedy.

Though The Merchant of Venice was first published as a comedy, it presents sadness and discontent in every moment of the play: Antonio opens the play saying that he is sad and weary; Portia complains about her weariness; Bassanio asks when the gentlemen will laugh; Jessica complains of tediousness, says that her house is a hell and she is sad during the whole play. Marjorie Garber, in Shakespeare after all (2004, p. 285) also points out that this uncomic atmosphere does not give much credit to the play to be a comedy. In addition to some critics who think that it is not a funny play, Shakespeare may have intentionally designed Shylock as a tragic character. Interestingly, the play's effects of Shylock's energy and tragic dimensions were noted in the very moment when it was first staged. According to Harold Goddard, on 22, July 1598, James Roberts published the play in the Stationers' Register with an alternative name: The Marchaunt of Venyce or otherwise called the Jewe of Venyce. It seems that the audience's aesthetic effects instigated Shakespeare to add a second name which drew attention to Shylock. For Goddard,

\begin{abstract}
Here is testimony that already in Shakespeare's own day the public was puzzled by the title of the play and had substituted for, or added to, the author's another title more expressive of what seemed to be its leading interest and central figure. The world did not have to wait for Kean and Irving to discover its 'hero'. [...] The public needed two titles. Shakespeare is content with two-in-one. (1969, p. 150).
\end{abstract}

This change of the name of the play suggests that the audience felt an astonishing and disquieting feeling in the first representation of the play. Against the Christians' ill-treatment to Shylock, it is difficult to see the play as a mere comedy. They never give back his money; they force his conversion into Christianity; they give half of his money to the State and half of money goes to Antonio and, later on, it must be given to Lorenzo, who married Jessica. It is noteworthy that they forget him in the last act and that they 
forget that they have just ruined a man. The final act's effacing effect creates feelings of discontent and anxiety in the audience, in the readers and in the characters of the play. Thus, such feelings are not fortuitously produced. Shakespeare actually created ambiguities that puzzle the audience and unleash disquieting and anguishing feelings after someone sees or reads the play. At the end of the play, the audience may feel constrained and uneasy of what happened to Shylock. Such feelings are the obscure uneasiness we may feel, because, at first, we laugh at Shylock's comic repetitive talking and then, reversibly, we eye-witness the cruelties that the Christians had impinged on him. We share the uneasiness provoked by the sensations and feelings of such opposing moments of the play.

The greatest problem of the play that makes uneasy to analyze it as a drama is the fifth act, with its effacing devices and the total forgetfulness of the cruelties that the Christians inflicted upon Shylock. The last act's effect is rather conflicting. The talking about love and romance, music and stars, the reconciliation of the couples Portia and Bassanio, Nerissa and Gratiano, who have just quarreled about their giving away their rings are over-determining elements which foreclose the sour effects of the fourth act. In that sense, according to Drakakis (1998),

The process that we see operating through the text of The Merchant of Venice is one which, with the benefit of hindsight, can be shown to constitute a systematic 'forgetting', effected through the conversion of Shylock, and the formal shift into the genre of comedy as a means of effecting closure. Whereas in tragedy what we experience is the isolation of the protagonist, in comedy the closure is usually one which incorporates participants into an inclusive definition of 'society'. (1998, p. 188)

Against Shylock's isolation and exclusion is necessary a comic and pretended happy ending to efface the play's sour effects. However, such closure is not dramatically convincing, since the play provokes a sort of bitter feeling at its end, which we try to reject or assimilate. This feeling provoked by such occlusion is disquieting and disturbing. However, some other elements point to sadness and discontent in the last act. Antonio ends the play completely alone. Like Shylock, he continues to be a sort of outcast of the play, a social outcast who is not happy. Likewise, Jessica remains sad and discontent in the final act. The opposing elements - festivity and sadness have annihilating effects in the audience and the reader. The play's aesthetic effect is thus rather conflicting and anguishing.

\section{Final Remarks}

Shakespeare's play The Merchant of Venice maybe considered a tragicomedy due to the ambiguous meanings provoked throughout the play. Shylock ends the play as an outcast, as well as Antonio and Jessica continue displaced in the happy encounter and reconciliation of the married couples. As a result, this effect may be the cause of the contradictory reading of play throughout the centuries and even our reading is affected by such disquieting effect, because the play leaves its meaning open at its end. It is not like other plays such as Hamlet, King Lear, Othello and Macbeth wherein desolation and death unleashes the socalled cathartic feelings. Indeed, The Merchant of Venice is rather an 'uncomic comedy' than a common festive comedy. The tragicomic figure of the play, Shylock, suffers his fate silently and becomes a scapegoat of the Christians' anxieties and sinister dimensions (COHEN, 2003).

Therefore, for this may be the first time Shakespeare created a drama wherein the silencing of a tragic figure causes an annihilating effect in the drama. In fact, Shylock is a tragic and comic figure, because he faces the final verdict impinged by Portia with his silence 'I am content', as well as he depicted with comic traits at the very beginning of the play. Later on, he faces life, tragedy and his fate as it is, as life really is. He is not a coward, just as he does not deny the consequences of bond: 'My deeds upon my shoulder', as he says (SHAKESPEARE, 2010, p. 348). He tragically accepts the consequences of his bond and his desire for revenge. Definitely, The Merchant of Venice is a tragicomedy. 


\section{References}

ADELMAN, Janet. Blood Relations: christian and jew in The Merchant of Venice.

Chicago: The University of Chicago Press: 2008. https:// doi.org/10.7208/chicago/9780226006833.001.0001.

ARISTOTLES. La Poétique. Paris: Éditions Seuil, 1980.

AUERBACH, E. Mimesis: a representação da realidade na literatura ocidental. São Paulo: Perspectiva, 2007a.

AUERBACH, E. Ensaios de Literatura Ocidental. Tradução de Samuel Titan Jr. e José Marcos Mariani de Macedo. São Paulo: Editora 34, 2007b.

CHARLTON, H. B. Shakespearian Comedy. London \& New York: Mathuen, 1984.

COETZEE, J. M. Doubling the Point: essays and interviews. Edited by David Attwell. Harvard: Harvard University Press, 1992.

COHEN, D. Searching Shakespeare: studies in culture and authority. Toronto: University of Toronto Press, 2003. https://doi.org/10.3138/9781442679689.

COOPER, J R. Shylock's Humanity. Shakespeare Quarterly, Vol. 21, No. 2, 1970, pp. 117-124. https://doi. org/10.2307/2868824.

COYLE, M. The Merchant of Venice: contemporary critical essays. Londres: Macmillan: 1998.

DILLON, J. Shakespeare's tragicomedies. WELLS, S; GRAZIA, M. The new Cambridge Companion to Shakespeare. New York: Cambridge, 2010. https://doi. org/10.1017/CCOL9780521886321.012.

DRAKAKIS, J. Historical difference and Venetian Patriarchy. In: COYLE, M. The Merchant of Venice: contemporary critical essays. Londres: Macmillan: 1998. p. 181-208.

FERREIRA, R. DE S. LUDWIG, C. R.; Life and Fiction: Imagination and Literary Creation in Atonement. Porto das Letras, v. 5, n. 2, p. 58-77, 2019.

GARBER, Marjorie. Shakespeare After All. New York: Anchor Books, 2004.

GRAHAM, Cary B. Standards of Value in The Merchant of Venice. Shakespeare Quarterly, Vol. 4, No. 2, 1953, pp. 145-151. https://doi.org/10.2307/2866172.

GROSS, K. Shylock is Shakespeare. Chicago: Chicago University Press, 2006. https://doi.org/10.7208/chicago/9780226309927.001.0001.

HINELY, J. Bond Priorities in The Merchant of Venice. Studies in English Literature, Vol. 20, No. 2, 1980, pp. 217-239. https://doi.org/10.2307/450170.

KAPLAN, M. L.; BEVINGTON, D. (orgs.). The Merchant of Venice: texts and contexts. New York: Palgrave, 2002

LUDWIG, C. R. Adaptação e Re-Criação de Ricardo III, de Al Pacino. Porto das Letras, Vol. 03, Nº 02. Jul.-dez., 2017.

LUDWIG, C. R. Inwardness and Subjectivity in Early Renaissance. Porto das Letras, Vol. 4, No 2. Jul.-dez. p. 134 - 157, 2018.
LUDWIG, C. R. Judgment, Conscience and Shylock's Bond. Porto das Letras, Vol. 6, No 1. Jan.-jun., p. 110139, 2020

MAGUIRE, Laurie M. Studying Shakespeare: a guide to the play. Oxford: Blackwell Publishing, 2004. https:// doi.org/10.1002/9780470775929.

MARLOWE, Christopher. The Complete plays. Edited by Frank Romany \& Robert Lindsey. London: Penguin, 2003.

MAUS, K. E. Inwardness and Theater in the English Renaissance. Chicago: Chicago University Press, 1995.

McGINN, Colin. Shakespeare's Philosophy: Discovering the Meaning behind the Plays. New York: Harper, 2007.

OXFORD DICTIONARY. Sally Wehmeier (Org.). $7^{\text {th }}$ edition. Oxford: Oxford University Press, 2010.

SHAKESPEARE, W. Complete Works. Londres: Wordsworth Editions, 2007

SHAKESPEARE, W. Hamlet. London: Arden, 1997.

SHAKESPEARE, W. Julius Caesar. London: Penguin, 1976.

SHAKESPEARE, W. King Lear. Essex: Longman, 1987.

SHAKESPEARE, W. Macbeth. London: Arden, 1997.

SHAKESPEARE, W. Richard III. New York: Matheun, 1997.

SHAKESPEARE, W. The Merchant of Venice. Londres: Arden, 2010

SHAPIRO, J. Shakespeare and the Jews. New York: Columbia University Press, 1996.

SHERMAN, A. Disowning knowledge of Jessica, or Shylock's scepticism. Studies in English Literature, 1500-1900, Vol. 44, No. 2, 2004, pp. 277-295. https://doi.org/10.1353/ sel.2004.0021.

\section{Carlos Roberto Ludwig}

Professor Adjunto da Universidade Federal do Tocantins - UFT. Doutor e Mestre em Letras pela Universidade Federal do Rio Grande do Sul - UFRGS. Graduado em Letras - Português, Inglês e Literaturas e Letras - Português, Francês e Literaturas pela Universidade Federal de Santa Maria - UFSM. Atualmente, é docente do Curso de Letras: Libras da UFT e atua como Docente Permanente e Coordenador do Programa de Pós-Graduação em Letras, do Campus de Porto Nacional/UFT.

\section{Endereço de correspondência}

Universidade Federal do Tocantins

Rua 03, quadra 17, Lote 11, S/N

Jardim dos Ipês, 77500000

Porto Nacional, TO, Brasil 